\title{
ДО ПРОБЛЕМИ ЕТИКО-ПЕДАГОГІЧНОЇ ВЗАЄМОДІЇ МАЙБУТНІХ МЕДИЧНИХ CECTEP
}

\author{
Л. Г. Гребенюк, О. І. Пилипишин \\ Тернопільський національний медичний університет \\ імені І. Я. Горбачевського мОЗ Украӥни
}

У статті окреслено аспекти етико-педагогічної взаємодії «студент - студент», «студент - викладач», «студент - практичний медичний працівник», "студент - пацієнт». Охарактеризовано специфіку формування професійної етики майбутніх медичних сестер.

\section{TO THE PROBLEM OF ETHICAL AND PEDAGOGICAL INTERACTION OF FUTURE NURSES}

\author{
L. G. Grebenyuk, O. I. Pylypyshyn
}

\section{Horbachevsky Ternopil National Medical University}

The article outlines the aspects of ethical and pedagogical interactions «student - student», «student - teacher», «student - practical nurse», «student - patient». It describes the specifics of the formation of professional ethics of future nurses.

Вступ. Організація етико-педагогічної взаємодії «студент - студент», «студент - викладач», «студент практичний медичний працівник», «студент - пацієнт», що $є$ наступною педагогічною умовою, можлива завдяки системному і систематичному формуванню духовно-ціннісного особистісного внутрішнього простору студентів. У такому просторі мають знайти відображення такі складники, як самопізнання, самоактуалізація, самовдосконалення, саморозвиток, самовираження, самоствердження [1].

Відтак вартісним $є$ бачення всесвітньо відомих майстрів теорії і практики виховання А. Макаренком і В. Сухомлинським особистості вихованця, його духовності, обов'язку, волі, відповідальності, потреби в гармонійному розвитку. У професійній діяльності викладачів медичного коледжу доцільно реалізувати концепцію паралельної педагогічної дії А. Макаренка [2], що знайшла відображення в ідеї виховання особистості в колективі, методи педагогічного впливу (дитячої радості, громадської думки, змагання) та педагогічної вимоги, які стимулювали його вихованців до свідомої організації свого життя.

Основна частина. Мудрість педагога концентрується і в його вмінні розуміти постійний стан са-

(c) Л. Г. Гребенюк, О. І. Пилипишин, 2021 моутвердження й самовиховання дитини, і в умінні розуміти мову дитинства [3]. Дослідники переконливо доводять, що міжособистісна взаємодія медичного працівника з пацієнтом спрямована на вирішення головного завдання медичної діяльності - видужання хворого, підтримку його фізичного і морального здоров'я [4]. Успішність вирішення такого завдання є можливою за умови правильної організації взаємовідносин.

Вагомим є діалог між однолітками. Організовуючи етико-педагогічну взаємодію «студент - студент», враховуємо вікові особливості: студенти вступили до медичного коледжу після одинадцяти класів загальноосвітньої школи. Важливими є процес адаптації до умов навчання, практики, професійної соціалізації вихованців, зміна середовища спілкування, перебування студентів у товаристві однокурсників, студентів старших курсів, медичних працівників. Усе це впливає на формування в них моральних суджень, уявлень про критерії моральної поведінки у професійній діяльності, на ступінь моральності, самостійності у виконанні окремих професійних дій, на комунікативну взаємодію, виконання спільних справ. Враховуємо також гендерний аспект: більшість середнього медичного персоналу становлять жінки, чим пояснюється 
материнська специфіка комунікативної взаємодії у професійній діяльності. Важливу роль відіграють студентське самоврядування та інститут кураторства, що планують колективні види діяльності студентів з урахуванням їх інтересів: проектування спільних волонтерських проектів, виконання громадських доручень тощо.

Ціннісно-етичною і естетичною має бути етикопедагогічна взаємодія «студент - викладач». Кожний викладач, куратор групи в медичному коледжі, на наше переконання, має володіти достатніми знаннями сестринської педагогіки, вікової, медичної, педагогічної психології і вмінням цей дорогоцінний досвід передати своїм молодим колегам. Високо оцінює роботу викладача відомий вчений І. Зязюн. Зокрема, дослідник пише: «Викладання у професійному навчальному закладі - це і мистецтво, і наука. Мистецтво тому, що кожне заняття неповторне. Його хід, емоційне забарвлення, використовувані засоби залежать від цілого ряду факторів, багато з яких важко передбачити. У цьому розумінні викладання чимось подібне до творчості художника, письменника, поета, від яких вимагається і глибоке знання життя, людської душі, уміння співпереживати особистості. Але разом з тим це і наука, в основі якої $є$ об'єктивні закони..., що забезпечують процес цілеспрямованого розвитку особистості професіонала» [5].

Специфіка естетико-психологічних чинників педагогічної взаємодії полягає в їх взаємозв'язку з ії афективною стороною, тобто з емоціями, почуттями, переживаннями їі учасників, які визначальним чином впливають на перебіг та результати цієї взаємодії, переконує О. Отич [6]. Завдання викладача як організатора педагогічної взаємодії полягає у «зараженні» студентів власними емоціями, інтересом, бажаннями опанувати навчальний предмет, який він викладає, у формуванні в них потреби з власної волі долучитися до запропонованої педагогом навчальної діяльності.

Доброзичливість, чуйність, терпимість, ненав'язливий вплив, захопленість благородною справою, людинолюбство, тактовність, вміння зрозуміти іншого, товариськість (на цьому наголошували свого часу П. Каптерьов, А. Макаренко, В. Сухомлинський, К. Ушинський та ін.) - ці якості викладача значною мірою знадобляться майбутнім медсестрам як педагогам. Секрети професіоналізму педагогів, які співпрацюють з майбутніми медичними сестрами, полягають насамперед у ґрунтовній підготовці до заняття, у поєднанні високої вимогливості та турботи про особистість студента як громадянина, патріота своєї професії, країни, громадянина світу.

Кваліфіковані поради, дії викладача, пов'язані 3 психопрофілактикою, психогігієною, психотерапією, психокорекцією, оздоровчо-реабілітаційними заходами, розгляд ситуацій взаємин між медпрацівником і хворим дозволяють студентам сестринського відділення глибше усвідомити труднощі та морально-ціннісні орієнтири майбутньої професії, серед завдань якої - налагодити особливу організацію спілкування із пацієнтом під час діагностики, власне лікування чи профілактичних оглядів.

Ефективними засобами розвитку діалогічної взаємодії на заняттях із предметів гуманітарного циклу можуть бути творчі завдання, робота у групах, у парах, конкурси. $€$ потреба у веденні дискусій, есе на основі професійно-орієнтованих текстів художньої літератури тощо. Це допоможе розвинути образну уяву, а через запитання, спонукання до дії ініціювати ціннісно-смислову комунікацію, внутрішній діалог й розумову активність студентів. Звичайно, таке спілкування можливе, коли колектив нагадує сім'ю, в якій панують чуйність, повага, здатність виявляти співчуття, вміння допомагати, тобто, де формуються кращі духовні цінності.

Діяльність викладача має бути спрямована на гуманізацію взаємин із студентами. На переконання І. Зязюна, основною функціональною одиницею, за допомогою якої проявляються всі властивості педагогічної діяльності, є педагогічна дія як єдність цілей і змісту [5].

Проведений аналіз наукових студій дозволив визначити основні ціннісні орієнтації та змістові установки наставника відносно студента: толерантність, спрямована на розуміння того, що всі вихованці індивідуальні й неповторні, кожний має право на власні погляди; емпатійне ставлення до студента, що передбачає прагнення і вміння відчувати іншого як самого себе, розуміти іншу позицію, інший внутрішній світ, відчувати і сприймати проблеми, переживання іншої людини; діалогізм як бажання і вміння слухати й чути студента, здатність подавати навчальний матеріал у формі відповіді на запитання, які виникають у студентів, «йти не з предметом до учня, а з учнем до предмета», здійснювати міжособистісний діалог на основі рівності позицій, взаємної довіри й поваги. Саме діалогічні стосунки сприяють гуманізації взаємин викладачів-кураторів і студентів.

Важливу роль у формуванні етико-педагогічної взаємодії з досвідченими фахівцями сестринської 
справи і залучення до традицій професійного медичного товариства відіграє виробнича практика. Часто, як показує опитування, у період практики, під час призначення ліків, медсестринського обстеження пацієнтів, студентам складно здійснювати вербальне спілкування, між пацієнтами і медичними працівниками виникають проблемні ситуації, в яких студенти не готові прийняти доцільні рішення. Завдання керівників практик - збагачувати вихованців професійним досвідом сестринського догляду, виховувати у студентів прагнення ретельно й цілеспрямовано спостерігати за поведінкою пацієнтів із метою надання якісної допомоги, забезпечувати морально-етичні відносини. Реалізується модель оптимальних взаємин, що ґрунтуються на співпраці та передбачають взаємоповагу, взаємодопомогу, взаєморозуміння, взаємодовіру, партнерські відносини, але з дотриманням субординації, толерантності, взаємоввічливості. Студент-практикант має в особі медичного працівника, медичної сестри бачити свого порадника і наставника, який може допомогти, скерувати, упередити від непрофесійних вчинків, байдужості, професійної недбалості, натомість медичний працівник, медична сестра - поважати особистість студента-практиканта, спрямовувати його професійні дії, вказуючи в делікатній формі на виявлені недоліки, щиросердно радіючи його професійним успіхам. Мета такої взаємодії - надати всебічну медичну, психологічну, моральну допомогу пацієнту. Для студента важливі знання основ конфліктології, комунікативної взаємодії з фахівцями, які мають різний професійний статус, уміння встановлювати з ними доцільні професійні й особистісні стосунки.

Виробнича практика має сприяти організації етикопедагогічної взаємодії «студент - пацієнт». Майбутній медичній сестрі важливо навчитися розуміти психологію людини, яка відчуває невпевненість, тривогу і страх за власне здоров'я та життя, фізичний біль, перебуває у стані пригніченості, роздратування. Необхідні знання таких якостей, як темперамент, характер, тип поведінки пацієнта, спостережливість, уміння помічати зовнішні, добре, аби і внутрішні зміни, все, що відбувається з пацієнтами. 3 комунікабельними пацієнтами (екстерналами), які часто бувають збудливими, викликають агресію, гнів, важливо передусім встановити емоційний контакт, а потім з'ясовувати більш вагомі дані щодо захворювання чи лікування. Пацієнтам, які «замкнені в собі» (інтернали), у своєму внутрішньому світі, необхідний спочатку нейтральний інформаційний контакт і лише поступово формування емоційного й оптимістичного ставлення до лікування. Особам, які до процесу лікування ставляться скептично, важливо методами навіювання, переконання, заохочення пояснювати ефективність процесу лікування, що призначено лікарем.

Необхідною умовою успішної етико-педагогічної взаємодії «студент - пацієнт» вважаємо дотримання культури слухання. Йдеться про вироблення відчуття присутності, сконцентрування уваги на іншій людині, що надзвичайно важливо у медичній практиці. Для ефективного слухання фахівці пропонують використовувати рефлексивний (передбачає активний зворотний зв'язок), емпатичний (передбачає виявлення співчуття і співпереживання), критичний стилі слухання (настанова на критичне сприйняття інформації), що ґрунтуються на певних мовленнєвих прийомах і потребують значних свідомих зусиль, комплексу знань і вмінь [7]. Для вміння слухати потрібні чутливість, розуміння, а також утримання від будь-яких суджень про іншу людину.

Висновки. Проведений аналіз медичної, педагогічної літератури дозволяє визначити комплекс умов, реалізація яких потрібна для забезпечення ефективності формування професійної етики майбутніх медичних сестер: розроблення і впровадження моделі формування професійної етики майбутніх медичних сестер; створення в медичному коледжі освітньо-виховного середовища, що сприяє позитивній мотивації студентів до формування професійної етики; забезпечення морально-етичної спрямованості змісту навчальної, практичної, професійної, виховної, громадської діяльності студентів.

\section{СПИСОК ЛІТЕРАТУРИ}

1. Щербан Т. Д. Психологія навчального спілкування : монографія / Т. Д. Щербан. - К. : Міленіум, 2004. - 345 с.

2. Макаренко А. С. Педагогіка індивідуальної дії / А. С. Макаренко: у кн.: Педагогічна майстерність : хрестоматія : навч. посіб. ; за ред. І. А. Зязюна ; упоряд.

І. А. Зязюн, Н. Г. Базилевич, Т. Г. Дмитренко та ін. - К. : СПД Богданова А., 2008. - С. 212-213.

3. Сухомлинський В. О. Роль переконань у формуванні духовного обличчя особистості / В. О. Сухомлинський // Вибрані твори : у 5 т. - К. : Радянська школа, 1977. - Т. 2. С. 389-421.

20 ISSN 2411-1597. МЕДСЕСТРИНСТВО. 2021. № 1 
4. Павлюк Т. М. Емпатійні чинники професійної адаптації медичних сестер : автореф. дис. на здобуття наук. ступеня канд. псих. наук : спец. 19.00.07 «Педагогічна і вікова психологія» / Т. М. Павлюк. - Івано-Франківськ, 2007. - 22 c.

5. Зязюн І. А. Філософія педагогічної дії : монографія / І. А. Зязюн. - Черкаси : ЧНУ імені Богдана Хмельницького, 2008. - 608 c.
6. Отич О. М. Розвиток творчої індивідуальності студентів професійно-педагогічних навчальних закладів засобами мистецтва : монографія / О. М. Отич ; за ред. I. А. Зязюна. - Чернівці : Зелена Буковина, 2011. - 248 с.

7. Янков А. В. Англійська мова для студентів-медиків: Анатомічна, клінічна і фармацевтична термінологія / А. В. Янков. - К. : Вища школа, 1998. - 175 с.

Отримано 18.02.21 